\title{
Zagrożenie hydratami podczas wydobycia płynów węglowodorowych z formacji łupkowych
}

\begin{abstract}
W artykule poruszono zagadnienia związane z kinetyką formowania się hydratów. Dokonano również przeglądu metod i technik laboratoryjnych dotyczących wyznaczania warunków termobarycznych powstawania hydratów gazowych. W publikacji zamieszczono także wyniki badań dotyczące warunków ciśnienia i temperatury (PT) formowania się hydratów gazowych dla węglowodorowych płynów złożowych pozyskanych z wykonanych dotychczas pozytywnie odwiertów z obszaru formacji łupkowych dolnego paleozoiku basenu bałtycko-podlasko-lubelskiego.

Słowa kluczowe: hydraty, płyny złożowe, formacje łupkowe.

\section{The potential danger from gas hydrates during the extraction of hydrocarbon fluids from shale formations}

The paper discusses issues related to the kinetics of the formation of hydrates. We also reviewed the methods and techniques of the laboratory determination of the (pressure and temperature) conditions of formation of gas hydrates. The paper also presents the results of the research on the conditions of pressure and temperature (PT) formation of gas hydrates for hydrocarbon reservoir fluids obtained from positively drilled wells in the shale formations of Lower Paleozoic of the Baltic-Podlasie-Lublin Basin.
\end{abstract}

Key words: hydrates, reservoir fluids, shale formations.

\section{Wprowadzenie do zjawisk formowania się hydratów gazowych}

Hydraty, określane czasem mianem wodzianów, należą do grupy ciał stałych zwanych klatratami lub inaczej związkami klatkowymi. Konstrukcja ich oparta jest na dwóch składnikach: osnowie i wypełnieniu. Cząsteczki wody stanowią osnowę w postaci przestrzennej sieci zawierającej wiele klatek. Z kolei cząsteczki gazu wypełniają puste klatki, stabilizując sieć, która nie może istnieć bez wypełnienia [9]. Cząsteczki wody tworzące konstrukcję klatki krystalicznej nie są związane chemicznie z zamkniętymi w nich cząsteczkami „gościa”, lecz jedynie przez oddziaływanie sił Van der Waalsa [8]. Hydraty mogą przybierać jedną z trzech struktur: typ I (sI), typ II (sII) lub typ H (sH - odkryta dopiero w 1987 r.). Wszystkie trzy typy hydratów zawierają wagowo około $85 \%$ wody (gospodarza), reszta to cząsteczki, przeważnie gazowej substancji hydratotwórczej (gościa). Strukturę I tworzą najmniejsze cząstki gazu, tj.: metan, etan, $\mathrm{CO}_{2}, \mathrm{H}_{2} \mathrm{~S}$; strukturę sII: cząsteczki propanu, izobutanu i azotu. Natomiast w skład sH wchodzą duże cząsteczki 2-metylbutanu, metylcyklopentanu, metylcykloheksanu i cyklooctanu, lecz tylko w obecności cząsteczek mniejszych, np. metanu [1]. Szersze omówienie struktur krystalicznych hydratów przedstawiono w wielu pracach $[3,9,14,19]$.

Najbardziej rozpowszechnione w przyrodzie są klatraty metanowe, jednakże hydraty tworzy ponad 130 substancji, w tym wszystkie podstawowe składniki gazu ziemnego [18]. Jest jeden warunek: cząsteczki - kandydatki do uwięzienia w lodowych celach, muszą mieć odpowiednie wymiary, pasujące do wielkości klatek [12]. Hydrat metanu sprawia w dotyku wrażenie ciepłego lodu. Jeśli temperatura wzrośnie lub ciśnienie zmaleje (albo oba zjawiska wystąpią łącznie), hydrat rozkłada się, wydzielając gazowy metan i wodę. Klatrat metanowy to bardzo skoncentrowane paliwo; $1 \mathrm{~m}^{3}$ hydratu, rozkładając się, daje około $160 \mathrm{Nm}^{3}$ metanu [5]. Inne źródła podają nawet wartości do $180 \mathrm{Nm}^{3}$ [14]. Procesowi formowania 
hydratu sprzyjają następujące czynniki: mechaniczne i fizyczne mieszanie, gromadzenie się w układzie cząsteczek stałych, wszelkiego rodzaju zarodki, niedoskonałości powierzchniowe reaktora i urządzeń pomocniczych, prędkość przepływu płynów (wpływająca na zmianę powierzchni międzyfazowej), przewężenia (mogące powodować efekt Joule-Thomsona) itd. Głównie wpływ mieszania w procesie hydratacji odgrywa ważną rolę w przyspieszeniu tworzenia się hydratów, co wiąże się ze zwiększeniem kontaktu wody z cząsteczkami gazu oraz zwiększaniem się stopnia wypełnienia klatek hydratowych poprzez rozrywanie większych aglomeracji krystalicznych, w których częściej zdarzają się puste klatki [8].

Z uwagi na powszechnie napotykane przez przemysł naftowy problemy z przytykaniem hydratami rurociągów, obecnie najbardziej rozwiniętą gałęzią wiedzy o hydratach są zagadnienia prewencji i inhibicji - tu skupia się gros prac badawczych. Potencjalne pozyskiwanie gazu ziemnego z krajowych formacji łupkowych także narażone jest na zagrożenia powodowane formowaniem się hydratów, które mogą pojawiać się już w rurach wydobywczych odwiertów. Z uwagi na stosunkowo niskie wydatki poszczególnych odwiertów wydobywczych (z którymi należy się liczyć w przypadku krajowych niekonwencjonalnych złóż typu shale gas) następuje zjawisko znacznego wychłodzenia gazu przepływającego ze złoża do głowicy odwiertu. Odbywa się to przy równoczesnym niewielkim spadku ciśnienia wydobywanego gazu. Należy zauważyć, że ciśnienia pierwotne złóż zlokalizowanych w polskich formacjach łupkowych, z racji znacznej głębokości zalegania, są wysokie. Dlatego już warunki odwiertowe stanowią dogodne środowisko dla formowania się hydratów. Ciśnienia rzędu kilkunastu - kilkudziesięciu $\mathrm{MPa}$ oraz niska temperatura (poniżej 30) stwarzają termodynamiczne warunki do inicjacji nukleacji. Zaczynają pojawiać się niewielkie zarodki nowej fazy materii, co początkuje proces hydratyzacji.

Przyjęto, że tworzenie się hydratu zachodzi w trzech etapach [15]:

1) nukleacja,

2) powolny wzrost hydratu,

3) gwałtowny wzrost hydratu.

Nukleację charakteryzuje czas indukcji, tj. czas potrzebny na uformowanie pierwszych kryształów przy danym ciśnieniu i temperaturze przechłodzenia. W warunkach statycz- nych do inicjacji hydratacji wymagane jest większe przechłodzenie niż w warunkach dynamicznych. Pierwsze ziarna hydratowe powstające $\mathrm{w}$ mieszaninie wody $\mathrm{z}$ gazem hydratotwórczym mają rozmiar 20 $\div 50 \mathrm{~nm}$ [4]. Mimo iż nie odgrywają one większej roli w przemyśle, to stanowią zarodki, na których nastąpi dalszy proces hydratacji. Stwierdzono również, że eksperymentalnie mierzony czas nukleacji jakościowo koreluje ze strukturą krystaliczną hydratu. Czas indukcji mierzy się poprzez obserwacje zmętnienia płynu lub pomiar konsumpcji gazu. Z molekularnego punktu widzenia przechłodzenie jest niewystarczającym parametrem do opisu nukleacji. Bardziej precyzyjny zdaje się być potencjał chemiczny [15]. Chociaż przechłodzenie lub odpowiednie sprężenie układu do warunków równowagowych zmienia potencjał chemiczny między cząsteczkami wody a cząsteczkami hydratotwórczymi, to może okazać się niewystarczające do utworzenia hydratu, ponieważ do pełnego opisu zjawiska brakuje energii wewnętrznej Gibbsa, związanej z chemicznymi własnościami oddziałujących cząsteczek [4]. Energia ta jest ukryta w wiązaniach Wan der Waalsa, utrzymujących hydrat, mimo iż warunki termodynamiczne układu odejdą od warunków równowagowych.

Powolny wzrost hydratu jest kolejnym etapem, w którym obserwuje się wyraźny przyrost objętości zarodka hydratowego, lecz nie jest on gwałtowny. Towarzyszy mu konsumpcja gazu oraz obniżenie ciśnienia w układzie [7]. W odpowiednio izolowanym układzie można również zanotować niewielki wzrost temperatury na zewnątrz hydratu, ponieważ tworzenie hydratu jest reakcją egzotermiczną i jej ciepło przechodzi do otaczającego roztworu. Obliczenie szybkości wzrostu hydratu daje jakościowy i ilościowy obraz zagrożenia zablokowania rurociągów i możliwość podjęcia stosownych środków zapobiegawczych.

Gwałtowny wzrost kryształów hydratowych to ostatni etap i różni się on od poprzedniego głównie dynamiką przebiegu.

Na podstawie badań tworzenia i wzrostu pojedynczych kryształów wywnioskowano, iż początkowo ignorowany transfer ciepła ma kluczowe znaczenie w dokładnym opisie kinetyki pojedynczych i złożonych kryształów [2]. Inne badania uściślają tę kwestię: tylko wzrost hydratu ograniczony jest transferem masy i ciepła [4]. Ponadto w odróżnieniu od nukleacji, wzrost kryształów spowolniony jest dyfuzją rozpuszczonego gazu w otaczającej hydrat wodzie [4].

\section{Przegląd metod służących do określania warunków formowania się hydratów}

Proces powstawania hydratów jest zjawiskiem występującym na powierzchniach kontaktu gazu i wody - dlatego podstawowym wymogiem konstrukcji aparatury badawczej jest zapewnienie pełnego kontaktu pomiędzy fazą ciekłej wody i gazem [10]. Można to osiągnąć dwoma sposobami: barbotując gaz poprzez warstwę wody lub wprowadzając go pod ciśnieniem do aparatury częściowo zapełnionej wodą. W drugim przypadku, dla zapewnienia warunków powstawania 
hydratów, należy ciągle odnawiać powierzchnię międzyfazową. Uwzględniając powyższe, wymienione metody nazwano w literaturze odpowiednio: dynamiczną i statyczną. W metodzie statycznej, jako częściej stosowanej w praktyce, dla zapewnienia odnawiania międzyfazowej powierzchni kontaktu, stosowane jest wewnętrzne mieszanie w komorze hydratów poprzez rotację, wstrząsanie lub oscylację komory [10]. Niekiedy wykorzystywane jest również magnetyczne mieszanie wewnątrz komory (metoda proponowana i stosowana obecnie w INiG - PIB). Innym rozwiązaniem jest wykorzystanie jedynie zjawiska dyfuzji. Pomiary tego typu, ze względu na niewielkie tempo mieszania gazu i wody, stwarzają jednak możliwość popełnienia znacznych błędów.

Jednym z najstarszych przykładów aparatury do wyznaczania warunków formowania się hydratów jest aparatura Deatona, zbudowana z wysokociśnieniowej komory hydratów wyposażonej w szklany wziernik o grubości $2 \mathrm{~cm}$, wytrzymujący ciśnienie do 180 bar. Ilość gazu przepływająca przez system jest regulowana odpowiednimi zaworami. Komora może być odchylana (na boki) od położenia horyzontalnejgo, lecz obserwacje wykonuje się zawsze przez wziernik w pozycji poziomej. Hydraty są wytwarzane przez wybór odpowiednich ciśnień i temperatur. Rozkład hydratu następuje drogą obniżki ciśnienia, chociaż aparatura jest również przystosowana do badań przy stałym ciśnieniu, a zmiennej temperaturze.

Podobną aparaturę zastosował Unruh i Katz [16]. Składniki gazowe mieszane były w oddzielnych komorach, skąd niezbędne ilości gazu wtłaczano przy pomocy rtęci do komory pomiarowej, znając dokładnie ich objętość. Komora mogła być obracana, zapewniając tym samym skuteczne mieszanie faz. Ciecz w komorze była oświetlana, co umożliwiało obserwację wizualną przebiegu zjawiska. Na początku doświadczenia komorę napełniono wodą destylowaną, następnie około połowy tej wody wypierano wtłaczanym gazem. Oziębiając komorę o $3 \div 4^{\circ} \mathrm{C}$ poniżej spodziewanej temperatury powstawania hydratu, utrzymywano ją w ruchu aż do chwili rozpoczęcia tworzenia się hydratu. Gdy hydrat już powstał, obniżano stopniowo ciśnienie do momentu zapoczątkowania rozkładu hydratu. Stan ten objawiał się wzrostem ciśnienia.

F. Scauzillo [13] zastosował komorę ze szklanym wziernikiem o objętości wewnętrznej $90 \mathrm{~cm}^{3}$, połączoną z wysokociśnieniową pompą rtęciową umożliwiającą regulację zakresu ciśnień. Temperatura była utrzymywana i regulowana z wykorzystaniem etylenoglikolu przepływającego przez spiralę wykonaną z miedzi i otaczającą komorę. Napełnioną komorę utrzymywano w określonej temperaturze przez około 15 minut, następnie po ustaleniu równowagi termicznej ciśnienie w komorze progresywnie zwiększano krokowo o 1,5 bar. W każdym kroku mieszano zawartość komory. Proces powtarzano do chwili wzrokowego zauważenia wydzielenia się hydratów. Warunki tworzenia się hydratów badano również przy stałym ciśnieniu, obniżając krokowo temperaturę aż do chwili pojawienia się hydratu.

E. Otto [11] stosował stalową komorę o zmiennej objętości wyposażoną w szklany wziernik. Jako uszczelnienie komory wykorzystano rtęć regulującą zarazem objętość czynną komory. Mieszanie faz osiągano, poruszając komorą, jednocześnie obniżano temperaturę. W konsekwencji powtarzanego procesu tworzenia i rozkładu hydratów otrzymywano satysfakcjonujące wyniki.

Nowszą generację stanowiska badawczego dla określania termodynamicznych parametrów dysocjacji hydratów zastosowali Dharmawardhana, Parrish i Sloan [6]. Wykorzystali oni oscylator ultradźwiękowy oraz mostkowy pomiar przewodności właściwej, co pozwalało śledzić ilość gazu i wody przechodzącej w stan hydratu.

Kolejną metodę badawczą służącą do wyznaczania warunków formowania się hydratów zaproponowano w Instytucie Nafty i Gazu - Państwowym Instytucie Badawczym [10]. Znajdujący się w INiG - PIB, w laboratorium PVT, zestaw badawczy Ruska przeznaczony jest do badań zjawisk fazowych w zakresie: od temperatury otoczenia do $177^{\circ} \mathrm{C}$, w przedziale ciśnień $0 \div 826$ bar. Wykorzystywany jest on do eksperymentalnego określania: ciśnienia nasycenia, punktu rosy, wykładnika gazowego, lepkości, krzywych równowagowych gaz-ciecz (izoterm kondensacji) oraz wielu innych tzw. parametrów PVT badanego płynu złożowego. Aparat wyposażony jest w komorę posiadającą trzy wzierniki szklane umożliwiające wizualną obserwację próbki w zadanych warunkach temperatury i ciśnienia. Komora badawcza może pracować zarówno w stanie statycznym, jak i dynamicznym, tzn. z mieszaniem faz. Osprzęt stanowią rtęciowe pompy wolumetryczne, manometry, termometry, zawory wysokiego ciśnienia i pojemniki ciśnieniowe. W celu umożliwienia prowadzenia badań nad określeniem warunków PT formowania się hydratów, „standardowy” zestaw PVT rozbudowano o freonową instalację chłodniczą mogącą obniżyć temperaturę w komorze badawczej do $0^{\circ} \mathrm{C}$ - rysunek 1 . Płyny przeznaczone do badań odpowiednio wprowadzano do wizualnej komory ciśnieniowej, a następnie układ złożony z właściwej ilości fazy wodnej i gazowej (z użyciem systemu mieszającego) doprowadzano do równowagi fazowej w zadanych warunkach termobarycznych. W drodze eksperymentalnych doświadczeń i obserwacji stanu fazowego badanej mieszaniny w komorze ustalono, że optymalna procedura badawcza polegać ma na zadaniu określonej temperatury i stopniowym podwyższaniu ciśnienia w komorze, aż do uzyskania/identyfikacji we wzierniku „obrazu” hydratu [10]. Z uwagi na fakt, że identyfikacja punktu formowania się hydratu opierała się na obserwacji wizualnej stanu fazowego 
badanej mieszaniny w komorze, należało się liczyć z pewnym błędem spowodowanym subiektywnym czynnikiem ludzkim. Niedogodność ta została wyeliminowana w ko- lejnej, niżej opisanej, technice badań hydratów gazowych (opracowanej w INiG - PIB) - tzw. metodzie ,tąpnięcia ciśnienia” - rysunek 2.

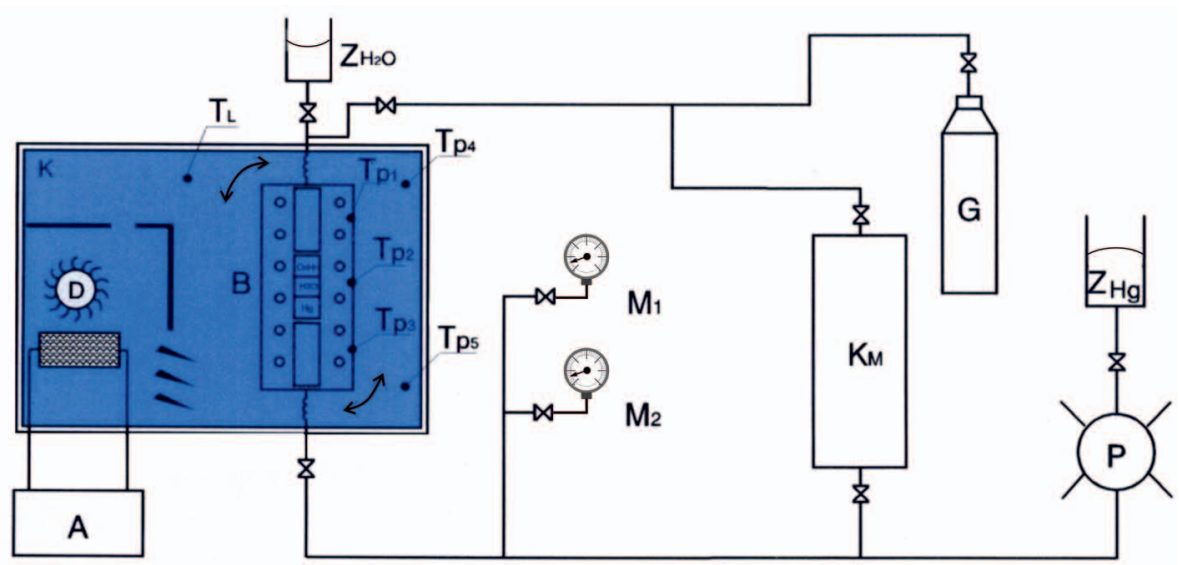

Rys. 1. Schemat aparatury badawczej INiG - PIB stosowanej do eksperymentalnego określania warunków powstawania hydratów [10]

$\mathrm{Z}_{\mathrm{Hg}}$ - zbiornik rtęci, $\mathrm{Z}_{\mathrm{H}_{2} \mathrm{O}}$ - zbiornik wody, $\mathrm{P}$ - pompa rtęciowa, $\mathrm{K}$ - komora termostatyczna, $\mathrm{A}$ - kriostat, $\mathrm{T}_{\mathrm{P} 1-3}$ - termopary, $\mathrm{T}_{\mathrm{L}}$ - termometr laboratoryjny, $\mathrm{D}$ - dmuchawa, $\mathrm{G}$ - butla $\mathrm{z}$ badanym gazem, $\mathrm{B}$ - trójokienna komora ciśnieniowa, $\mathrm{K}_{\mathrm{M}}$ - komora manipulacyjna
Określanie warunków formowania się hydratów metodą „tąpnięcia ciśnienia" polega na wykorzystaniu zjawiska polegającego na anomalnym obniżaniu się ciśnienia w układzie podczas formowania się hydratu. W trakcie izochorycznego obniżania temperatury systemu gaz-woda rejestrowany jest monotonny spadek ciśnienia w układzie, przebiegający według równania stanu gazu (przy nieznacznym wpływie zjawiska rozpuszczania się gazu w wodzie). W momencie osiągnięcia w schładzanym układzie warunków równowagowych formowania się hydratów zaczyna następować zjawisko transferu faz (konsumpcja gazu) i cząsteczki gazu stopniowo więzione są w strukturach

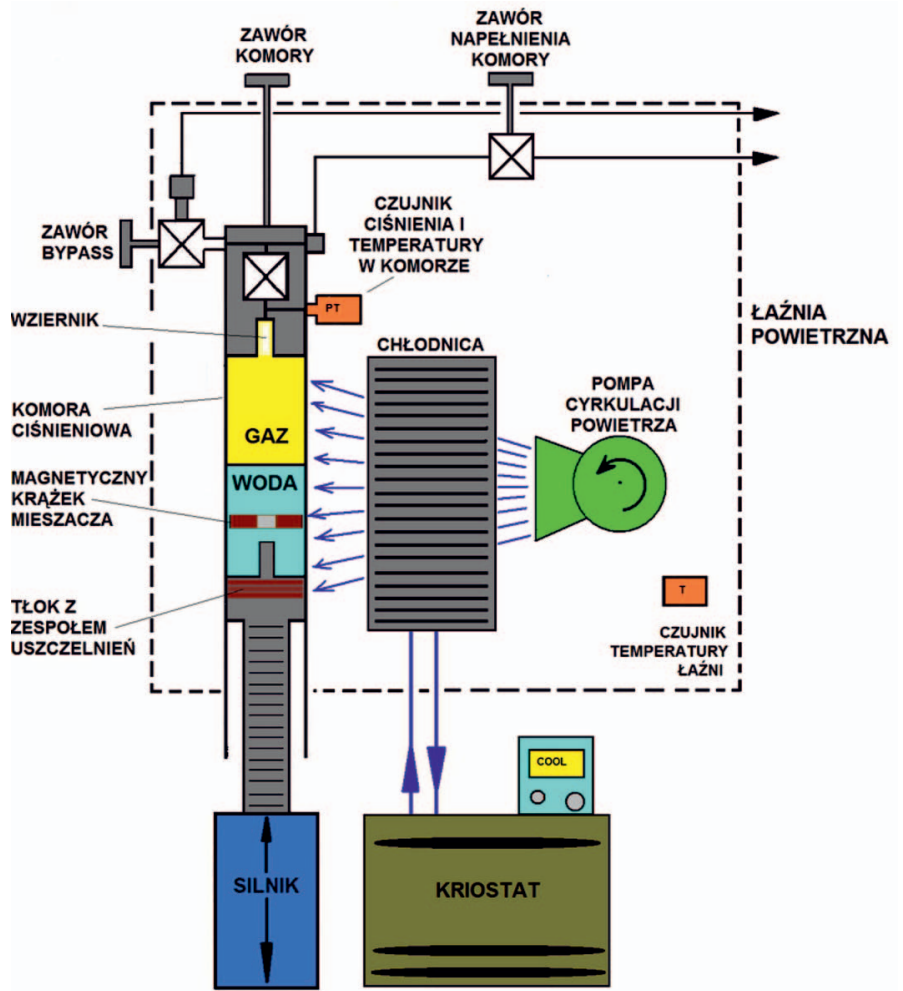

Rys. 2. Schemat poglądowy stanowiska badawczego do eksperymentalnego określania warunków formowania się hydratów metodą „tąpnięcia ciśnienia” [17] klatek tworzonych z cząsteczek wody - powstaje hydrat. Cząsteczki wody stanowią osnowę w postaci przestrzennej sieci zawierającej wiele klatek; z kolei cząsteczki gazu wypełniają puste klatki, stabilizując sieć, która nie może istnieć bez wypełnienia.

Do badań zjawisk formowania się hydratów ww. metodą wykorzystano nowoczesną aparaturę PVT, którą wyposażono w kriostatyczny układ chłodzący z możliwością precyzyjnej regulacji temperatury, a przede wszystkim - tempa schładzania układu komory ciśnieniowej.

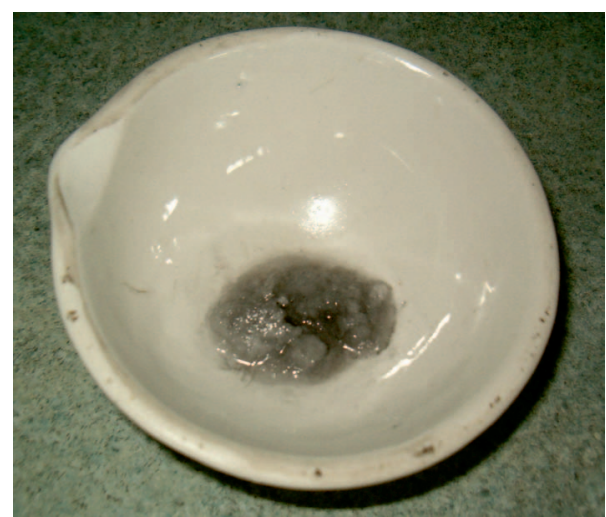

Rys. 3. Hydrat na etapie rozkładu, wydobyty z komory badawczej [17]

\section{Badania warunków formowania się hydratów dla krajowych gazów pochodzących z formacji łupkowych}

Badania warunków termobarycznych formowania się hydratów przeprowadzono z użyciem metody „tąpnięcia ciśnienia”, czyli izochorycznego schładzania mieszaniny gazowo- wodnej przy zadanym ciśnieniu panującym w układzie. Poboru próbek do badań dokonywano podczas testów produkcyjnych prowadzonych dla danego odwiertu. Woda wypływająca 
$\mathrm{z}$ odwiertu, razem z gazem pochodzącym z dolnopaleozoicznych formacji łupkowych, okazała się być zanieczyszczona cieczą pozabiegową - zwrotną, pochodzącą z przeprowadzonego zabiegu szczelinowania hydraulicznego. Woda zawierająca liczne dodatki jest nieodpowiednia do prowadzenia zaplanowanych badań hydratów gazowych. W związku z powyższym została ona zastąpiona wodą słodką, demineralizowaną - w dużej mierze odpowiadającą wodzie kondensacyjnej - powszechnie wydzielającej się z gazu przepływającego odwiertem wydobywczym ze złoża na powierzchnię.

W tablicy 1 przedstawiono 3 uproszczone składy gazów pochodzących z odwiertów udostępniających polskie dolnopaleozoiczne formacje łupkowe basenu lubelskiego, dla których sprawdzano zagrożenie zjawiskiem formowania się hydratów.

Tablica 1. Skład i parametry badanych gazów

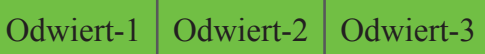

\begin{tabular}{|l|r|r|r|}
\hline $\mathrm{CH}_{4}[\% \mathrm{~mol}]$ & 61,4 & 68,0 & 84,2 \\
\hline $\mathrm{C}_{2+}[\% \mathrm{~mol}]$ & 31,4 & 26,2 & 11,9 \\
\hline $\mathrm{N}_{2}[\% \mathrm{~mol}]$ & 6,3 & 4,9 & 3,6 \\
\hline $\mathrm{CO}_{2}[\% \mathrm{~mol}]$ & 0,7 & 0,4 & 0,2 \\
\hline $\mathrm{He}[\% \mathrm{~mol}]$ & 0,2 & 0,6 & 0,1 \\
\hline Gęstość $\left[\mathrm{kg} / \mathrm{Nm}^{3}\right]$ & 1,04 & 1,12 & 0,79 \\
\hline Ciepło spalania $\left[\mathrm{MJ} / \mathrm{m}^{3}\right]$ & 52,8 & 55,6 & 45,0 \\
\hline
\end{tabular}

Głównym składnikiem użytych mieszanin jest metan oraz cięższe frakcje węglowodorowe - w tablicy 1 oznaczone jako $\mathrm{C}_{2+}$. Wśród niewęglowodorowych składników należy wymienić azot i ditlenek węgla. Gazy nie zawierają siarkowodoru. W każdym z trzech gazów zidentyfikowano pewną koncentrację helu, która - zwłaszcza dla gazu pochodzącego z odwiertu $\mathrm{nr} 2$ - zawiera się na poziomie kwalifikującym do rozważenia potencjalnego przemysłowego odzysku w instalacjach kriogenicznych. Gaz pobrany do badań z odwiertu nr 2 charakteryzuje się ponadto największą gęstością oraz wysoką wartością energetyczną, wyrażoną parametrem ciepła spalania na poziomie $55,6 \mathrm{MJ} / \mathrm{Nm}^{3}$.

Badania przeprowadzono w szerokim zakresie ciśnień, zapewniającym ,pokrycie" warunków termobarycznych przypływu gazu w rzeczywistych warunkach odwiertowych - zwłaszcza w przypowierzchniowym odcinku odwiertu, gdzie zwykle występuje stosunkowo wysokie ciśnienie i niska temperatura. Eksperymenty wykonano również w obszarze niższych ciśnień - rzędu kilkudziesięciu bar. Warunki takie spotykane są powszechnie w napowierzchniowych

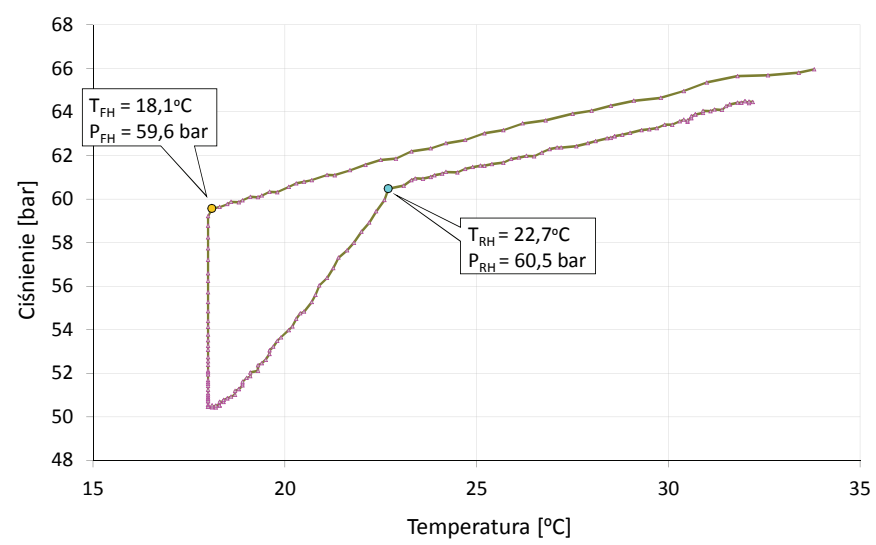

Rys. 4. Zależność ciśnienia w funkcji temperatury układu wyznaczenie punktu formowania się $\left(\mathrm{P}_{\mathrm{FH}} ; \mathrm{T}_{\mathrm{FH}}\right)$ i rozpadu hydratów $\left(\mathrm{P}_{\mathrm{RH}} ; \mathrm{T}_{\mathrm{RH}}\right)$

instalacjach zagospodarowania odwiertu oraz $\mathrm{w}$ ciągach przesyłowych, transportujących płyn węglowodorowy do ośrodka zbiorczego czy kopalni.

Na rysunku 4 przedstawiono przebieg zmian parametrów ciśnienia w funkcji temperatury $\mathrm{w}$ trakcie prowadzenia jednego z eksperymentów badawczych.

Na rysunku 5 zobrazowano przebieg badania w czasie. Przedstawiono zmiany temperatury oraz ciśnienia w trakcie badania, naniesiono punkty zinterpretowane jako punkt formowania się i całkowitego rozpadu hydratu. Strefę zawartą pomiędzy wyznaczonymi punktami definiuje się jako obszar metastabilności hydratów [9].

Na podstawie uzyskanych wyników z kilku badań wykreślano krzywe formowania się oraz dysocjacji hydratów dla każdej mieszaniny wodno-gazowej pochodzącej z badanych odwiertów - rysunek 6. Linią ciągłą zaznaczono krzywe tworzenia się hydratów, natomiast linią przerywaną, w tym samym kolorze, krzywe równowagowe rozpadu. W sumie

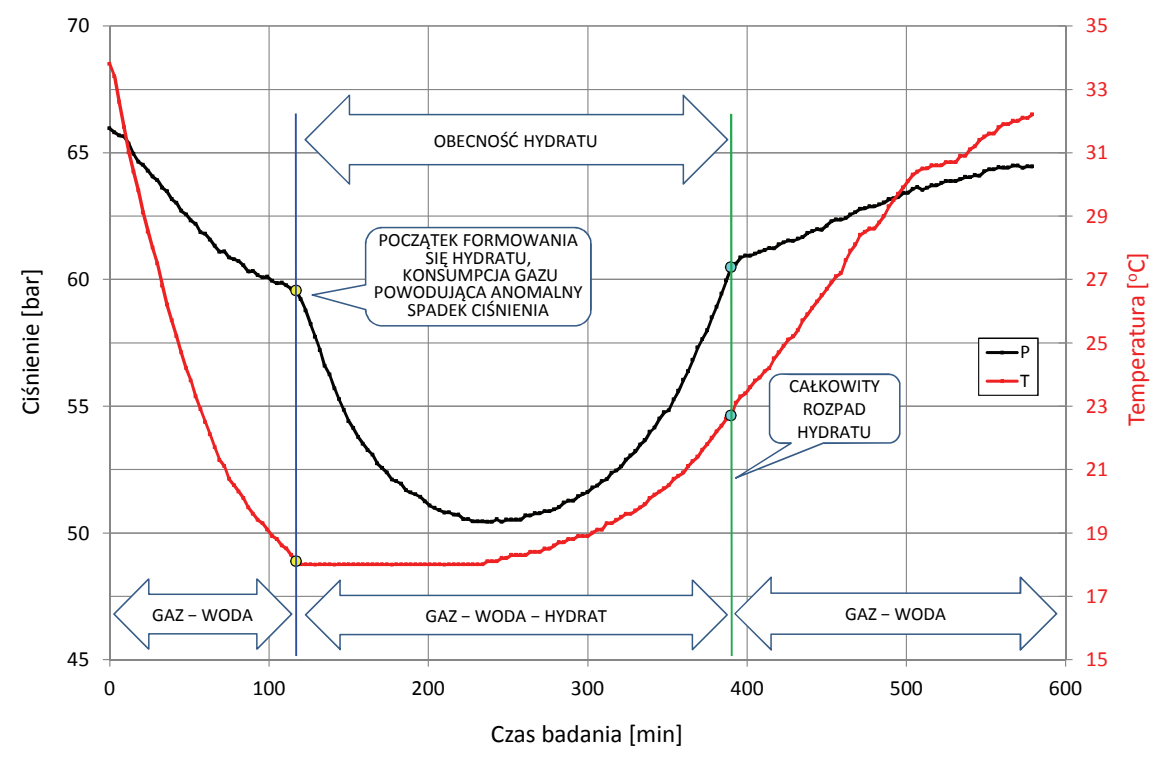

Rys. 5. Przebieg badania - zmiany ciśnienia i temperatury układu w funkcji czasu 
wykonano 13 eksperymentów, w trakcie każdego z nich wyznaczano dwa istotne punkty, tj.: formowania i rozpadu hydratu w zadanym ciśnieniu.

Gazy z odwiertów 1 i 2 wykazały się bardzo zbliżonym obszarem PT występowania hydratów, ich krzywe równowagowe gaz-woda-hydrat przebiegają względem siebie równolegle, a przesunięte są o niespełna $1^{\circ} \mathrm{C}$. Wynika to stąd, że poszczególne składniki tych gazów przejawiają podobne właściwości hydratotwórcze. Krzywa równowagowa hydratów dla gazu z odwiertu nr 3 jest przesunięta o około $3^{\circ} \mathrm{C}$ w kierunku niższych temperatur w stosunku do krzywych dwóch pozostałych gazów. Badania wykazały, że gaz ten jest najmniej podatny na formowanie się hydratów. Wiąże się to z jego składem, w którym dominuje metan, a składników zgrupowanych we frakcje $\mathrm{C}_{2+}$ jest zdecydowanie mniej.

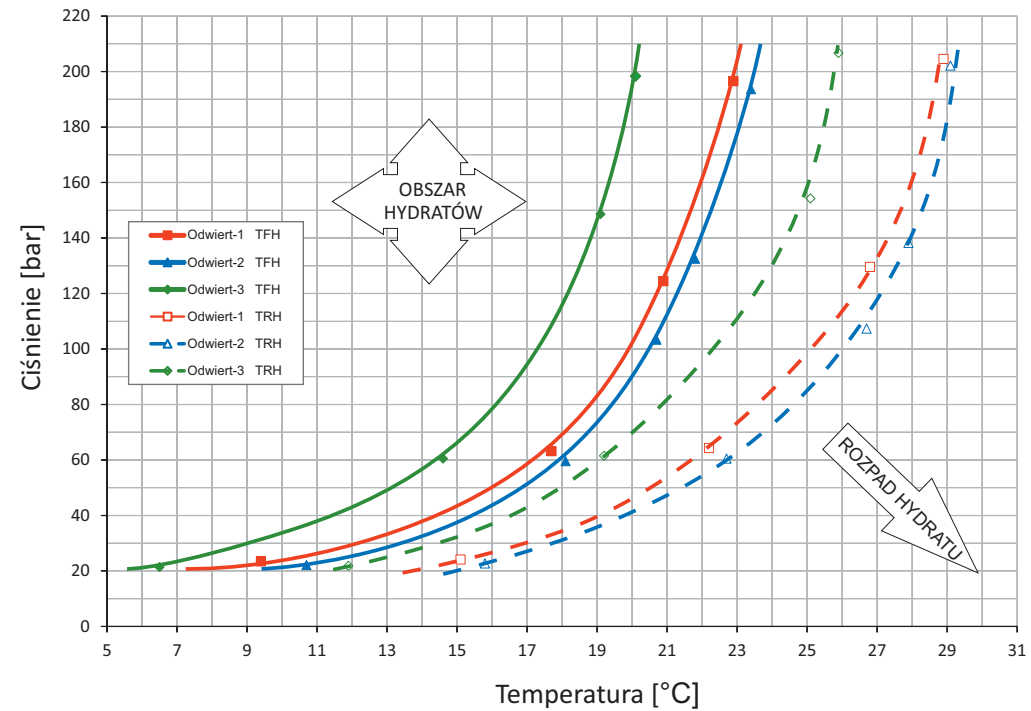

Rys. 6. Krzywe PT hydratów - wyznaczone eksperymentalnie

Linie ciągłe - krzywe formowania się hydratu, linie przerywane - krzywe rozpadu hydratu

\section{Podsumowanie}

Problemy stwarzane przez obecność hydratów w rurociągach podczas procesów towarzyszących eksploatacji złóż węglowodorów pojawiają się coraz częściej na całym świecie. To zauważalne rozpowszechnienie zjawisk formowania się hydratów związane jest poniekąd $\mathrm{z}$ udostępnianiem do eksploatacji coraz głębiej zalegających złóż gazu czy ropy. Prowadzone od kilkudziesięciu już lat, $w$ wielu renomowanych ośrodkach, wnikliwe badania warunków formowania się hydratów $\mathrm{w}$ gazie ziemnym oraz zaprezentowane $\mathrm{w}$ artykule rzeczywiste wyniki badań laboratoryjnych płynów pochodzących z krajowych formacji łupkowych potwierdzają, że szczególne zagrożenie hydratem występuje w obszarze wysokiego ciśnienia i niskiej temperatury. O ile w napowierzchniowej części instalacji zagospodarowania odwiertu wydobywczego głównym „katalizatorem” hydratu jest niska temperatura przepływającego rurami gazu, o tyle w samych rurach wydobywczych odwiertu problemem staje się stosunkowo wysokie ciśnienie.

Nasycony parą wodną gaz ziemny wpływający ze złoża do odwiertu posiada wysoką temperaturę - odpowiadającą przeważnie temperaturze złożowej, która z kolei wynika $\mathrm{z}$ gradientu geotermalnego panującego $\mathrm{w}$ danym systemie złożowym. Gaz przemieszczając się w górę, wzdłuż odwiertu, stosukowo łatwo i szybko wychładza się, by na głębokości kilkuset metrów osiągnąć temperaturę poniżej $30^{\circ} \mathrm{C}$.

Cechą charakterystyczną towarzyszącą wydobyciu gazu z formacji łupkowych są stosunkowo niskie wydajności. Stąd mała wartość strumienia cieplnego związanego z przepływem masy wydobywanego płynu wzdłuż odwiertu. $Z$ uwagi na powyższe, rury eksploatacyjne nie są odpowiednio „wygrzane” przez wypływające ze złoża media - zachowują temperaturę zbliżoną do wynikającej z gradientu geotermalnego panującego na danej głębokości, dlatego następuje szybkie schładzanie wydobywanego gazu. W miarę zbliżania się do głowicy odwiertu, w odpowiednio niekorzystnych warunkach, temperatura gazu może się nawet zrównać z temperaturą atmosferyczną. Problem niskiej temperatury nasila się zwłaszcza w okresie zimowym. Przepływowi gazu odwiertem towarzyszy nie tylko spadek temperatury, ale również ciśnienia. Jednakże redukcja ciśnienia zachodząca wzdłuż odwiertu, zwłaszcza gazowego, jest stosunkowo niewielka - o wiele mniejsza niż stopień wychładzania się gazu. Ponadto podczas obniżania się temperatury i ciśnienia $\mathrm{z}$ fazy gazowej wykrapla się odpowiednio faza ciekła w postaci kondensacyjnej wody o praktycznie zerowym stopniu zmineralizowania, co dodatkowo sprzyja wodzianom. Powstają idealne warunki dla uformowania się hydratu.

W celu zapobiegania problemom wynikającym z przytykania rurek wydobywczych (także rurociągów napowierzchniowych) przez hydraty, można stosować szereg metod prewencyjnych. Wśród najważniejszych wymienić należy:

- skuteczne osuszanie gazu z wilgoci (obniżenie punktu rosy pary wodnej),

- unikanie obniżenia temperatury gazu poniżej temperatury formowania się hydratów,

- unikanie ciśnień przewyższających ciśnienia formowania się hydratów,

- zatłaczanie inhibitorów termodynamicznych, np. metanolu, glikolu etc., w celu efektywnej redukcji temperatury formowania się hydratu $\left(\mathrm{T}_{\mathrm{FH}}\right)$, by zahamować lub wystarczająco opóźnić krystalizację hydratu,

- zatłaczanie inhibitorów kinetycznych dla zapobieżenia 
nagromadzeniu się kryształków hydratu, a w konsekwencji utworzenia korka hydratowego.

Wszystkie ww. metody prewencyjne wymagają znajomości przebiegu krzywych równowagowych systemu gaz-woda-hydrat. Są to wyznaczane różnymi, po części opisanymi w artykule, sposobami diagramy P-T hydratów; zwane również krzywymi hydratów - rysunek 6. Najkorzystniej jest, gdy krzywą hydratów określa się laboratoryjnie z użyciem rzeczywistych próbek gazu i wody pobranych z głowicy/separatora danego odwiertu. Metody symulacyjne (komputerowe) obarczone są błędem dotyczącym niedoskonałości oznaczenia składu chemicznego badanych mieszanin gazowo-wodnych. Jak zaprezentowano, krzywe hydratów określane obecnie w INiG - PIB wyznaczane są eksperymentalnie tzw. metodą „tąpnięcia ciśnienia". Krzywa rozdzielająca obszar zagrożenia hydratem od obszaru „bezpiecznego” kreślona jest na podstawie minimum czterech punktów pomiarowych. Poszczególne punkty określa się w procesie izochorycznego ochładzania odpowiednio przygotowanej mieszaniny gazowo-wodnej w warunkach intensywnego mieszania faz. Metoda ta jest bardzo dokładna, powtarzalna i pozbawiona czynnika subiektywnego - towarzyszącego metodom wizualnym. Proponowana metodyka umożliwia ponadto określenie warunków PT rozpadu/dysocjacji (już utworzonego) hydratu, czyli w połączeniu z krzywą formowania - obszaru metastabilności hydratu. Takie informacje dają niemal pełny obraz zjawisk związanych z zagrożeniem hydratowym, a właściwie wykorzystane są niezwykle pomocne podczas zarządzania eksploatacją danego złoża.

Prosimy cytować jako: Nafta-Gaz 2016, nr 8, s. 619-625, DOI: 10.18668/NG.2016.08.05

Artykuł nadesłano do Redakcji 4.03.2016 r. Zatwierdzono do druku 27.04.2016 r.

Artykuł powstał w oparciu o wyniki prac badawczych uzyskane w efekcie Projektu ResDev realizowanego w ramach Programu Blue Gas - Polski Gaz Łupkowy.

\section{Literatura}

[1] Atilhan M. et al.: Natural Gas Hydrates in Advances in Natural Gas Technology. Edited by Dr. Hamid Al-Megren, InTech 2012, s. 193-212.

[2] Bollavaram P., Devarakonda S., Selim M. S., Sloan E. D. Jr.: Growth Kinetics of Single Crystal sII Hydrates Elimination of Mass and Heat Transfer Effects. Annals of the New York Academy of Sciences 2000, vol. 912, s. 533-543.

[3] Carroll J. J.: Natural gas hydrates, a guide for engineers. Gulf Professional Publishing 2003.

[4] Christiansen R. L., Bansal V., Sloan E. D. Jr.: Avoiding Hydrates in the petroleum industry: Kinetics of Formation. SPE 1994, 27994.

[5] Ciechanowska M.: Niekonwencjonalne węglowodorowe źródła energii-gazohydraty. Nafta-Gaz 2014, nr 10, s. 724-727.

[6] Dharmawardhana P., Parrish W., Sloan D.: Experimental thermodynamic parameters for the prediction of natural gas hydrate dissociation conditions. Industrial \& Engineering Chemistry Fundamentals 1980, nr 19.

[7] Lorenc M.: Hydraty w transporcie gazu. Rurociągi 2007, vol. 47, nr 1, s. 3-11.

[8] Lorenc M., Warowny W.: Odsiarczanie gazu ziemnego metoda hydratacji. Nafta-Gaz 2009, nr 2, s. 158-167.

[9] Lubaś J.: Doświadczalno-teoretyczne studium zjawisk powstawania i dysocjacji hydratów gazu ziemnego. Prace Instytutu Górnictwa Naftowego i Gazownictwa nr 117, Kraków 2002.

[10] Lubaś J.: Hydraty w głębokich odwiertach gazu ziemnego - prognozowanie i zapobieganie. Prace Instytutu Górnictwa Naftowego i Gazownictwa nr 93, Kraków 1998.

[11] Otto E.: A study of hydrates in the methane-propylene-water system. AICHE (4), 1960, s. 28-31.

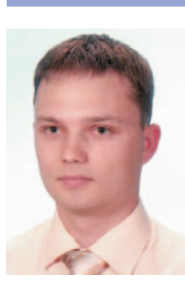

Mgr inż. Sławomir SZUFLITA

Asystent w Zakładzie Badania Złóż Ropy i Gazu.

Instytut Nafty i Gazu - Państwowy Instytut Badawczy

ul. Lubicz 25 A

31-503 Kraków

E-mail: slawomir.szuflita@inig.pl
[12] Rutkowski M.: Hydraty - czyżby przyczyna tajemniczych zjawisk $w$ trójkącie bermudzkim? Wiedza i Życie 2002, nr 11.

[13] Scauzillo F.: Clathrate Hydrates of Natural Gases. Chemical Engineering Progress 1956, vol. 52, s. 115-118.

[14] Sloan Jr E. D.: Clathrate hydrates of natural gases. Marcel Dekker, Inc., New York 1998.

[15] Svartaas T. M., Kelland M. A., Dybvik L.: Experiments Related to the Performance of Gas Hydrate Kinetic Inhibitors. Annals of the New York Academy of Sciences 2000, vol. 912, s. 744-752.

[16] Unruh C., Katz D.: Methane Hydrate at High Pressure. Petrol. Trans. 1949, AIME 186, s. 83-86.

[17] Warnecki M., Biały S.: Adaptacja bezrteciowej aparatury PVT dla badań warunków formowania się hydratów metoda ,tapnięcia ciśnienia”. Praca statutowa Instytutu Nafty i Gazu 2008, nr zlecenia: $32 / \mathrm{KB}$.

[18] Warowny W., Lorenc M.: Wykorzystanie zjawiska hydratacji gazów. Wiertnictwo Nafta Gaz 2009, tom 26, zeszyt 1-2.

[19] Werner F. Kuhs et al.: Formation of Porous Gas Hydrates from Ice Powders: Diffraction Experiments and Multistage Model. American Chemical Society. The Journal of Physical Chemistry B, 2003, vol. 107, nr 37, s. 10299-10311.

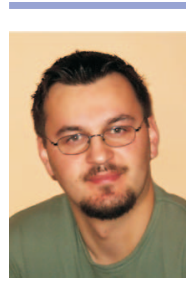

Dr inż. Marcin WARNECKI

Kierownik Zakładu Badania Złóż Ropy i Gazu. Instytut Nafty i Gazu - Państwowy Instytut Badawczy ul. Lubicz 25 A

31-503 Kraków

E-mail: marcin.warnecki@inig.pl

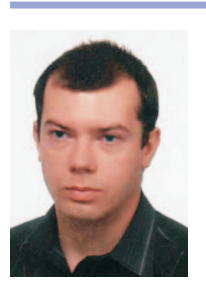

Mgr inż. Jerzy KUŚNIERCZYK

Specjalista badawczo-techniczny w Zakładzie Badania Złóż Ropy i Gazu.

Instytut Nafty i Gazu - Państwowy Instytut Badawczy ul. Lubicz 25 A

31-503 Kraków

E-mail: jerzy.kusnierczyk@inig.pl 